\title{
Externalization or imitation: the 2015-16 asylum- seeker immigration as a catalyst for local structural change
}

\section{Miriam Schader}

To cite this article: Miriam Schader (2020): Externalization or imitation: the 2015-16 asylumseeker immigration as a catalyst for local structural change, Ethnic and Racial Studies, DOI: 10.1080/01419870.2020.1763417

To link to this article: https://doi.org/10.1080/01419870.2020.1763417

\section{(c) 2020 The Author(s). Published by Informa UK Limited, trading as Taylor \& Francis} Group

\section{央 Published online: 14 May 2020.}

Submit your article to this journal $₫$

\section{Џ Article views: 184}

Q View related articles 


\title{
Externalization or imitation: the 2015-16 asylum- seeker immigration as a catalyst for local structural change
}

\author{
Miriam Schader
}

Max Planck Institute for the Study of Religious and Ethnic Diversity, Göttingen, Germany

\begin{abstract}
When in 2015-2016, several hundred thousand new asylum-seekers arrived in Germany, this put local administrations to a test. In contrast to scholars who identified a "crisis of the administration" or a situation of "state failure", this article argues that the events in some cases served as a motor for administrative change. Drawing on the sociology of organizations, the paper shows that this period is better understood as a time of fundamental uncertainty rather than a crisis of the administration, and that the local state proved capable of dealing with uncertainty. In line with theories of organizations and based on qualitative interview data collected in three German cities, the paper identifies two ideal-typical strategies for reducing uncertainty - externalization or change through imitation. The text demonstrates how two of the three municipalities moved towards change.
\end{abstract}

ARTICLE HISTORY Received 19 August 2019; Accepted 22 April 2020

KEYWORDS Local migration policies; European migration crisis; uncertainty; organizational change; asylum-seekers and refugees; local refugee reception

In 2015, the already stretched Common European Asylum System (CEAS) and several national asylum systems in Europe were close to collapse. Although increasing numbers of refugees ${ }^{1}$ had been reaching European states since 2012, the European Union had not been able to find solutions for the most pressing problems of the CEAS. When numbers peaked in 2015 - in order to remove pressure from the system and to avoid a humanitarian emergency - the German Federal Government decided not to reject a large number of people, who came to Germany via other EU states - despite the option to send them back in accordance with EU legislation. Instead, it decided to process their asylum applications in Germany by applying the sovereignty 
clause foreseen in the EU Dublin Regulation. As a result, several hundred thousand people entered Germany within a few months.

According to many media sources, as well as scholarly, accounts, the period following this decision was a "migration" or "refugee crisis", which led to a crisis of the administration. Some academic authors even speak of a situation of "state collapse" or "state failure" (e.g. Hesse 2015; Hahlen and Kühn 2016). In contrast, this article argues that the state was generally well equipped to deal with this situation. ${ }^{2}$ Based on empirical studies in selected cities, this contribution will show that, in some cases, the events were even a motor for administrative change and instigated $\mathrm{a}$ - if belated - local adaptation to migrationinduced diversity.

As local administrations are decisive for the reception and inclusion of newcomers, the much-cited "crisis of the administration" should have manifested itself primarily there. It is thus essential to broaden our understanding of how local administrations adapted to the rapid refugee immigration.

This is relevant, as the reception and inclusion of refugees is a specific, but nonetheless empirically and theoretically interesting case for analyzing change and stability of local welfare administration. By studying the pressure on local administrations in 2015-16, we can learn more about the perceived "crisis" and the functioning of local administrations as well as local structural change. Furthermore, the reception of asylum-seekers and their inclusion into the welfare system can be considered a small, but in many ways indicative part of social policy. It is in many ways typical for how the welfare state generally treats those depending on benefits (cf. Schader forthcoming).

Literature on local migration policies - defined here as local instruments and measures designed to govern migration and migration-induced diversity (Schammann 2018,68) - has grown over the last decade (e.g. among many others: Caponio and Borkert 2010; Glick Schiller and Çaglar 2010; Jørgensen 2012; Filomeno 2017; Baumgärtel and Oomen 2019; Caponio, Scholten, and Zapata-Barrero 2019; Kühn and Münch 2019; Martínez-Ariño et al. 2019; Schiller 2019; Moutselos et al. 2020). ${ }^{3}$ Since the early 2010s, research on refugee immigration to Europe has greatly increased, too, with special attention to integration (Kleist 2018). Especially the local reception and inclusion have received much scholarly attention (e.g. Doomernik and Glorius 2016; Dick and Schraven 2017; Bygnes 2019). There is also a growing literature on local administrations and officials in the realm of asylum and refugee reception (e.g. Ellermann 2006; Eule 2014; Dahlvik 2017).

What is still partly understudied and under-theorised, however, is the perception of the 2015/16 immigration movement by local officials and its local repercussions, and, significantly, its longer-term consequences. The present study contributes to filling this gap. It presents original data on three German municipalities and the ways they dealt with the new immigration. Drawing on Apelt's and Senge's work on organizations and uncertainty 
(2015), the paper argues that the period in 2015-16 should more appropriately be described as a time of fundamental uncertainty, and not as a "crisis of the administration" or "state failure". I thus emphasize the ability of the local state to adapt to the challenges. Based on qualitative interview data, I identify two types of organizational strategies of uncertainty reduction externalization and change through imitation. The article thus adds to our understanding of local migration policies and organizational change.

\section{Research design and data}

The analysis is based on a comparison of two medium-size cities (NorthernCity, SouthernCity) and one smaller city (SmallNorthernCity) in the regional state of Lower Saxony. In order to counter the "extreme case bias" evidenced in much research on local migration policies (Schammann et al. forthcoming), three "ordinary" cities were selected. They are "ordinary" insofar as they are neither particularly large nor small, and, significantly, at the time of case selection, they neither stood for radically open or radically closed policies regarding migrant reception and inclusion. In addition, there are also important differences between the cities, which make a triangular comparison particularly useful.

By focusing on three municipalities in one regional state ${ }^{4}$, it is furthermore possible to keep the legal and political context "constant". This is important because the federal states largely determine the leeway municipalities have in accommodating refugees. The regional states are in charge of implementing federal law, and local administrations are part of the regional state. Regional ordinances may specify details of the implementation and thus instruct the local authorities (Schader 2019, 383-386). Although the municipalities have some discretion and also have to deal with legal and planning uncertainties, it is therefore important to study cases within one regional state and thus within the same institutional framework.

In all three city councils, the Social Democrats (SPD) are strongest, followed by the Christian Democrats (CDU) and the Green Party; all mayors (Oberbürgermeister) belong to the SPD. SmallNorthernCity has the highest number of representatives of the extreme right Alternative für Deutschland (AfD) in its city council. ${ }^{5}$ NorthernCity and SouthernCity are university cities with more than 165,000 and 130,000 inhabitants respectively, while the former industrial city SmallNorthernCity only has around 80,000 inhabitants. All three municipalities have their own Foreigners' Authorities, Ausländerbehörde, concerned with legal status, deportation, and similar issues. ${ }^{6}$ The proportion of people with a migration history is significantly lower in NorthernCity than in the other two cities. While in NorthernCity, the share of the population with a "migration background"7 is estimated at 16 per cent (as of 2010), shares are higher in SouthernCity (24-27 per cent in 2018) and in SmallNorthernCity 
(28 per cent 2010). NorthernCity is also the wealthier city. Here, the disposable income per household is above the regional average, while it is below in both SmallNorthernCity and SouthernCity. In smaller SmallNorthernCity, GDP per capita is also significantly lower than in the other two municipalities, and the unemployment rate is higher (Jacobs and Bolz n.d.).

The data was collected in the form of interviews with members of the three municipal administrations (from low to high-ranking officials) and volunteers over a period of three years (January 2017 to January 2020). ${ }^{8}$ These captured in retrospect - the experiences during the peak of refugee immigration as well as changes in the administrative structures during and after this phase. Additionally, the analysis draws on a corpus of primary documents, issued by the municipalities (including their concepts for integration, reports on refugee reception etc., local statistics), media reports in local newspapers as well as information gathered at visits to relevant locations (including accommodation centres) between 2015 and 2020. The analysis of the interview data and the corpus of documents was based on qualitative content analysis.

\section{Analytical framework}

The CEAS, including the Dublin Regulation, forms a European legal framework, in which federal and regional state asylum policies and laws are integrated. After registration at the German border, asylum-seekers are usually assigned to a regional "first-reception centre". From there, they are distributed to municipalities in the respective regional state. Between summer 2015 and spring 2016, a large number of asylum-seekers were additionally allocated directly to municipalities by the regional states within the framework of administrative assistance (Amtshilfe), because first-reception facilities had no more capacities. In addition to rising allocation quota, municipalities thus had to provide places for asylum-seekers who should have been accommodated in regional reception centres. They therefore needed to react flexibly and quickly to the situation. Often, they had to deal with new arrivals of refugees daily with only short notice and had to provide accommodation and initial care, clothing, translation and further support virtually overnight. Local administrations as organizations were therefore confronted with a rapidly changing environment during this period.

In order to define theoretically more precisely the uncertainties municipalities had to process, it is helpful to draw on concepts borrowed from the sociology of organizations. Apelt and Senge (2015, referring to Dequech 1999) distinguish between risk, incertitude and fundamental uncertainty. Risk means a relatively low degree of uncertainty: the relevant stakeholders are aware of the probabilities of environmental conditions to occur, which depend on their decisions. It is unknown which condition will occur. Incertitude refers to a situation in which possible future conditions arising from a 
decision are known, but due to a lack of information or cognitive skills it is unknown how likely their occurrence is. Fundamental uncertainty arises from the reflexivity of social interactions. Here, neither all possible conditions are known, nor can probabilities be attributed (Apelt and Senge 2015).

Risk and incertitude thus denote situations, in which potential future developments are foreseeable. If an actor in situation $A$ opts for action $B$, outcome C, D or perhaps E will occur. In a situation of risk, it is also known how likely C, D or $\mathrm{E}$ will occur. Under conditions of incertitude, these probabilities are unknown. Fundamental uncertainty describes a situation, in which, due to complex social interactions, it is neither clear what changes can occur in an organization's environment, nor with what probability something will happen. However, while such a situation is characterized by a lack of knowledge - what outcomes are possible? How probable is it that environmental state $Y$ occurs if I choose action $X$ ? - it also creates space for creativity (Dequech 1999). Finally, but relevantly, even under conditions of fundamental uncertainty, organizations still have to produce reliable outcomes (Apelt and Senge 2015, 3).

If we now apply this model to the reception of asylum-seekers in Germany, we can argue that risk and incertitude are the daily business of officials in this realm, whereas fundamental uncertainty rarely occurs. Risk is, for instance, inherent to the German system of regional and local asylum-seeker allocation. Due to the quota system, officials usually know that a maximum number of $x$ new asylum-seekers will be sent to their municipalities within a certain period. They do not know the actual composition of the new arrivals nor their precise needs, but based on statistics and earlier experiences, they can calculate probabilities. Most likely, more men than women will arrive, more accompanied than unaccompanied minors etc. Thus, it is possible to estimate the need for accommodation, translation, health services, places in schools ... - based on known probabilities.

Incertitude is, for example, observable when the federal or state governments introduce new measures or rules and municipalities can foresee the intended outcomes, but do not know if the new measures or rules are effective. When the federal government introduced the "80-cents-job" programme for asylum-seekers (FIM) ${ }^{9}$, for instance, municipalities knew that a certain number of places would be available in their regional state, but they did not know how efficient the measure would be or whether it would work at all. Thus, municipalities at the time created "80-cents-jobs" without knowing how likely these would be filled.

Fundamental uncertainty, in contrast, is less likely to occur on a regular basis as previous experiences, statistics and regulations usually make either potential future developments or probabilities or both (more or less) foreseeable. If the quota system for the local allocation of newly arrived refugees collapses, however, or laws and regulations at the state, federal or European 
Table 1. Risk, incertitude and fundamental uncertainty in local refugee reception.

\begin{tabular}{|c|c|c|}
\hline Risk & $\begin{array}{l}\text { Potential future developments are } \\
\text { foreseeable, probabilities are } \\
\text { known }\end{array}$ & $\begin{array}{l}\text { General characteristic of asylum-seeker } \\
\text { reception; arises for instance when quota } \\
\text { are known but the exact composition of the } \\
\text { respective number of asylum-seekers is } \\
\text { unknown }\end{array}$ \\
\hline Incertitude & $\begin{array}{l}\text { Potential future developments are } \\
\text { foreseeable, probabilities are } \\
\text { unknown }\end{array}$ & $\begin{array}{l}\text { More substantial form of uncertainty that } \\
\text { arises, for example, when new measures or } \\
\text { regulations are introduced at the state or } \\
\text { federal level and municipalities do know } \\
\text { the potential effects but not, how likely } \\
\text { they will materialize }\end{array}$ \\
\hline $\begin{array}{r}\text { Fundamental } \\
\text { uncertainty }\end{array}$ & $\begin{array}{l}\text { Potential future developments are } \\
\text { not foreseeable and probabilities } \\
\text { are unknown }\end{array}$ & $\begin{array}{l}\text { Exceptional situation; when legislation, } \\
\text { regulations, statistics etc. do not provide } \\
\text { enough knowledge about potential } \\
\text { developments and the likelihood of their } \\
\text { occurrence }\end{array}$ \\
\hline
\end{tabular}

levels do not seem to apply any longer, neither future developments nor probabilities are known (Table 1).

Municipalities as organizations have different options for dealing with situations of risk, incertitude or fundamental uncertainty. In the case of risk, it is most rational for them to decide according to the probabilities they know. Based on statistics, experience and the availability of accommodation, for instance, municipalities may provide a certain number of places in accommodation centres or private housing. In situations of incertitude, decisions depend on either local policy- and decision-making or on routines within the administration (cf. Eule 2014). They may also turn to higher levels of policy-making, e.g. in order to obtain a regional ordinance taking responsibility off them or clarifying the situation (Head of Department, NorthernCity).

Situations of fundamental uncertainty resemble those of incertitude insofar as members of the administration rely on political decisions or have to come up with their own solutions. At the same time, periods of fundamental uncertainty open up space for more creative forms of adaptation, due to their more radical and substantial character (cf. Dequech 1999). It is thus reasonable to expect that municipalities, while under pressure, could use the period of rapid refugee immigration for organizational change and adaptation or rely on strategies of externalization in order to reduce the uncertainty they face.

This is in line not only with Apelt's and Senge's conceptualization, but, despite different theoretical premises, also with new institutionalist approaches to organizational behaviour under conditions of uncertainty. From this point of view, the most likely forms of adaptation to a situation of fundamental uncertainty that can be expected are change through imitation - or in new institutionalist terms: mimetic isomorphism (DiMaggio and Powell 1983, 151) - and externalization. While it is possible that municipalities as organizations develop entirely new structures and measures in order to reduce uncertainty and to prevent future situations of fundamental 
uncertainty, it is more likely that they draw on a model or several models. Just like in a situation of incertitude, they may as well choose to shift responsibility off them by relying on other actors for reducing uncertainty.

Despite the proclaimed local turn in migration research, the theorization of local migration policies is less developed than theories for the national level or for the multi-level governance of migration (cf. Scholten and Penninx 2016; Scholten 2019). It is all the more useful to draw on existing theories and concepts. In their work on active and passive local migration policy-making, Schammann and his colleagues propose a valuable synopsis of different explanatory approaches (Schammann et al. forthcoming). While very broad, it is also helpful for making sense of the different local responses to the period of rapid refugee immigration. Schammann et al. (forthcoming) distinguish between the institutional framework, mainly made up of the legal and political setting, structural conditions, especially a municipality's demography, rurality / urbanity and financial situation, framing / political culture which refers to different frames of migration, diversity and (demographic) change, and agency / key actors including individual and collective stakeholders in order to identify factors that explain a municipality's active or passive stance on migration.

For the present analysis, it is important to note that the legal and political setting is mainly defined by policies and legislation at the EU, federal and regional state levels. Since all three municipalities are located in Lower Saxony, the institutional framework is the same. As outlined above, the structural conditions differ to a degree, with SouthernCity and NorthernCity being structurally more alike than SmallNorthernCity.

\section{“My civil servant's heart was bleeding": experiencing risk, incertitude and fundamental uncertainty in local refugee reception}

In accordance with the quota for the distribution of asylum-seekers in Germany, Lower Saxony received over 9 per cent in 2015 (as in the years before and after). Between summer 2015 and spring 2016, SouthernCity, NorthernCity and SmallNorthernCity received several hundred asylumseekers. The respective allocation quota were repeatedly adjusted to the situation, as were the numbers of people to be admitted additionally within the framework of administrative assistance. At peak times, all three cities accommodated around one hundred newly arrived refugees each week (NorthernCity 2016; Head of Unit 1, SouthernCity). At the end of 2016, around 1400 asylum-seekers lived in SouthernCity. In SmallNorthernCity the highest number was around 1200 and in NorthernCity around 2000 (NorthernCity 2016; SouthernCity 2016; Head of Office, SmallNorthernCity).

From the point of view of the local administrations, this period represented an immense challenge. It was characterized above all by the higher numbers 
and the rapidity of new arrivals and the lack of political and organizational preparation. Although the number of asylum applications in Germany had already risen before summer 2015, the federal and regional governments had failed to ensure sufficient reception capacities in cooperation with the municipalities.

Not only did many people come to local refugee centres without registration or without having filed their asylum application, the municipalities also had no advance information about numbers, characteristics and needs of the new arrivals. At times, they relied on the information transmitted by the bus drivers, who counted their passengers. Moreover, after the 2015 decision, it was not clear how many people would altogether be allowed to enter the country and over what period of time. For the municipalities this increased not only the incertitude immensely as probabilities were no longer known. The fact that the Dublin regulation was applied very differently than before - i.e. by making use of the sovereignty clause and not sending people back - created a situation of uncertainty where future events were not foreseeable:

This becomes particularly clear in a quotation from a head of department from SmallNorthernCity, in which he describes how unorganized and for the municipalities hardly plannable the distribution of the new immigrants took place. Due to the short-term nature of the admissions, the municipalities constantly had to improvise. A second quotation, from SouthernCity, further illustrates the unpredictability of the future as perceived by officials responsible for refugee reception.

The fact that all this was done very, very disorderly by the federal government at that time is a completely different story. So my civil servant's heart was bleeding. I admit that quite openly. So I had huge problems at that time with the way it was done, people were just sent here according to the motto: Now you get off the bus and from now, you can do whatever you want. I still don't think that's right, but that's another story. (Head of Office, SmallNorthernCity)

The [quota; MS] was 1200 at the time. The quota says nothing. The quota is a number that is given at a particular time, in other words, it was then mid-December 2015, when this huge quota came. And then, there is no end. A quota starts on a day, but they do not tell you, when it ends. The timeframe is not fixed. (Head of Unit, SouthernCity)

While all interview partners describe situations of increased risk and incertitude, the general perception of the situation was one of uncertainty marked by unpredictable effects of political events and decisions. For all three local administrations, the period 2015/16, before the main migration routes were closed, can in Apelt's and Senge's terms be described as a phase of fundamental uncertainty. Knowledge about possible environmental conditions - Who will come when? Who will have which needs? What decisions, regulations and funding by state and federal governments can be expected? Etc. - and about the respective probabilities was missing. 
Three main factors can be identified as leading to this fundamental uncertainty: (1) time and numbers (i.e. the fact that higher - and partly unknown numbers of individuals seeking protection arrived in a short period of time), (2) the contingency of future developments (will political leaders negotiate a closure of important migration routes? will the role of municipalities in the multi-level system of refugee reception remain the same?) and (3), closely related to (2), a high number of important changes in German legislation within a short period of time. ${ }^{10}$

These created an exceptional situation as all responsible officials note. In their eyes, however, this cannot be characterized as a situation of failure of the state or the administration. Although all three municipalities emphasize that they had reached their limits and criticized legislative decisions at higher levels, emphasis on their ability to cope with the situation is equally prevalent. The following excerpts from interviews with responsible officials underline this:

We have been able to do it, so far. We have been able to do it, but that is// if this is a priority in the country for a certain period, then it is a true statement: "Wir schaffen das" [we can do it]. [...] We have been able to do it and above all, the emphasis is, the municipalities were the ones who have done it, weren't they? [...] we did the work. (Head of Department, SouthernCity)

But crisis, I believe, in my view, this is not the right term. Last week [...] we had the opportunity to introduce our work to our apprentices. And I reflected on past events and said that it was an incredibly exciting time, because we were lucky that, if you were still sitting in the office at ten in the evening or on Saturdays, then you were not sitting there alone, because you saw that in the office to the left and right the lights were still on. And that was a time that also brought people together and created a sense of community. [...] Something like that gets to you, one could not keep up for a long time this way, this pace. But [...] it was also an incredibly positive experience, because you had the chance to perform. And because you just perceived that everyone really contributed and no one evaded responsibility. (Head of Unit, NorthernCity)

In various interviews, the term "crisis" was used to describe the time when many refugees arrived in the municipalities virtually overnight, when information gaps were large and the workload was high. Contrary to what is often argued, however, it is not the collapse of structures that is evident at the local level, but the functioning and increased cohesion of different organizational units and individual officials - albeit under conditions of increased uncertainty and strain.

\section{Reducing uncertainty and envisaging structural change}

As outlined above, organizations - including municipalities - have different options for dealing with increased uncertainty. In the short-term all three focussed cities relied on emergency measures combined with strong 
support by civil society actors, mainly volunteers. A quote from SouthernCity illustrates, how officials opted for routines created for - different - exceptional situations in order to reduce uncertainty quickly:

[...] And we therefore chose a work organisation that corresponds to our plans for disaster relief. So please do not understand me as if I was saying the arrival of refugees was a disaster. But we had to try in some way to accommodate people in dignity. (Head of Unit, SouthernCity)

The cooperation of different organizational units outside their line activities and across hierarchies and portfolios were central to this form of dealing with fundamental uncertainty. With some small exceptions, the forms of cooperation in all three municipalities were similar. The three municipalities differ, however, in the degree to which they emphasize emergency measures. While officials and bureaucrats in SouthernCity focus particularly strongly on the exceptional character of the situation, their colleagues from NorthernCity and SmallNorthernCity more often refer to existing and newly created structures that facilitated dealing with the fundamental uncertainty of the time. Furthermore, the two northern municipalities undertook additional steps towards longer-term adaptation already in 2015, while SouthernCity did not.

As expected, two types of medium- and long-term uncertainty reduction can be identified: externalization and organizational change through imitation. While SouthernCity can be described as an almost ideal-typical case of externalization, NorthernCity clearly belongs to the second category. SmallNorthernCity followed a mixed strategy of both externalization and imitation (Table 2).

SouthernCity's externalization strategy goes hand in hand with a quick return to the status quo ante and is evident at two levels: a reliance on higher levels of decision-making and a delegation of refugee reception to other municipalities and the regional state. When the numbers of newly arrived asylum-seekers had fallen from spring 2016 onwards, SouthernCity quickly returned to the habitual work organization. Neither were new organizational structures created nor did the municipality aim at an anticipatory adaption to potential future migration. Strikingly, the structure and tasks of the "Integration Office" (Büro für Integration) remained unchanged - although the Office is only a small staff unit, consisting of one fifty-percent position (Interview with Head of Office, SouthernCity). In contrast to the perception of the situation in the two northern municipalities, in the eyes of responsible SouthernCity officials, the events of 2015-16 had not disclosed deficits that required more substantial change. Rather, the city relied on federal and state policies to ease the situation:

[...] if this had gone on like this now, yes, if there had not been any deal with some [countries; the author] in Southeast Europe and further, and if the neighbouring countries [...] had continued to let everyone cross the borders, yes, then 
Table 2. Types of uncertainty reduction.

\begin{tabular}{|c|c|c|}
\hline & Type 1: Externalization & $\begin{array}{l}\text { Type 2: Organizational change through } \\
\text { imitation }\end{array}$ \\
\hline Focus & $\begin{array}{l}\text { - Immediate challenges and short-term } \\
\text { "disaster relief" measures } \\
\text { - Limited capacities }\end{array}$ & $\begin{array}{l}\text { - Immediate challenges and short-term } \\
\text { measures } \\
\text { - Limited capacities, but "impressive" } \\
\text { capabilities, flexibility and solidarity } \\
\text { - Previous successes in dealing with } \\
\text { diversity }\end{array}$ \\
\hline \multirow{2}{*}{$\begin{array}{l}\text { Uncertainty } \\
\text { reduction }\end{array}$} & Externalization: & Change: \\
\hline & $\begin{array}{l}\rightarrow \text { delegation of refugee reception to other } \\
\text { municipalities or break in allocation } \\
\rightarrow \text { relying on policies and legislation at higher } \\
\text { levels } \\
\rightarrow \text { no new structures or significant changes }\end{array}$ & $\begin{array}{l}\rightarrow \text { new agencies and structures imitating } \\
\text { model municipalities }\end{array}$ \\
\hline Cases & SouthernCity, [SmallNorthernCity] & NorthernCity, SmallNorthernCity \\
\hline
\end{tabular}

the point would have come when we would not have been able to deal with this any longer [...]. (Head of Department, SouthernCity)

Furthermore, SouthernCity refused to meet the reception quota set by Lower Saxony in 2015/16 and insisted instead on having to accept only as many people as the city, in their view, had places available (Head of Unit). Although the situation in many municipalities in Lower Saxony was comparable - their housing markets had already been tense before 2015 and the accommodation of newcomers was challenging - SouthernCity thus refused to accept responsibility for some of the people assigned to the city and expected them to be accommodated elsewhere.

Responses in SmallNorthernCity and NorthernCity were different. Both followed the examples of pioneering municipalities and created new structures to facilitate a long-term adaptation to migration movements. In these two cases, we therefore observe change through imitation - in more institutionalist terms: isomorphism - as the central strategy of uncertainty reduction.

Important references like Cologne, Freiburg or Wuppertal were models that were available in this situation, because they had already undertaken substantial restructuring in the realm of refugee-reception, migration and diversity. Significantly, Freiburg had used the rapid arrival of refugees for particularly comprehensive changes that had been envisaged before and could then be implemented quickly. Their newly founded Office for Migration and Integration unites various tasks in this area. Most remarkably, it integrates, as subordinate part, the Foreigners' Authorities, which in most municipalities is part of the Department for Order and Code enforcement. According to the Head of Office, "integration" thus has become the central goal of an agency charged also with deportation, legal status and similar matters ${ }^{11}$ (Head of Office, Freiburg). 
NorthernCity and SmallNorthernCity did not go as far, but took inspiration from the reforms in Freiburg and other municipalities (Head of Office, Head of Unit, NorthernCity; Head of Unit, SmallNorthernCity). A new Office for Immigration and Integration was founded in NorthernCity and in SmallNorthernCity the new unit Child Subsistence Allowances, Immigration and Integration was introduced.

Both cities started in 2015 to adapt their structures not only to the shortterm situation marked by fundamental uncertainty, but also to its longerterm consequences. Under the impression of the events, a "small office" (Head of Unit, NorthernCity) for Central Refugee Management was founded in NorthernCity in 2016. This in turn resulted in 2017 in the establishment of the larger Office for Immigration and Integration that unites two new units - for Refugee Management and for Integration. In this newly created office, in addition to the Head of Office and the two Heads of Unit, nineteen employees are responsible for different areas of Refugee Management and sixteen for Integration (Head of Office, Head of Unit, Head of Unit, NorthernCity). In relation to the size of the city, this is a considerable investment. The unit Refugee Management involves various tasks previously assigned to different units and, in some cases, to different departments (Head of Unit, NorthernCity). Likewise, the Integration Unit includes tasks and employees previously based in different units and departments (Head of Unit, NorthernCity). Importantly, the head of this unit is at the same time the city's Integration Officer, which strengthens the latter position, because the Integration Officer thus is not only responsible for conceptual and committee work, but can also shape decisively the way in which migration-related diversity is dealt with in practice.

In smaller and less prosperous SmallNorthernCity, a restructuring in the area of migration and refugee reception had already been planned before 2015, but had been postponed due to major financial problems at the municipal hospital (Head of Department, SmallNorthernCity). However, SmallNorthernCity, too, did not only focus on short-term emergency solutions. 150 Integration Guides - volunteers, who accompany new migrants during their first months (or years) of settling in the city - received new contracts from 2015 onwards, thus strengthening existing support structures in light of the events (Head of Department, SmallNorthernCity). In addition, a Coordination Office for Refugees and Intercultural Affairs was founded, made up of two social workers for refugees, who closely cooperated with the existing Coordination Office for Migration and Participation and which was further expanded in 2016 (Coordinator for Migration and Participation, SmallNorthernCity).

Following the example of NorthernCity (Head of Unit, SmallNorthernCity), administrative structures in SmallNorthernCity were further adapted in 2018: related tasks and structures were merged in the new unit Child 
Subsistence Allowances, Immigration and Integration. The new structures and first experiences in NorthernCity had explicitly served as a model; the unit is, however, considerably smaller than in the neighbouring city. Like in NorthernCity, the existing staff unit Coordination Office for Refugees and Intercultural Affairs became part of the new unit and various tasks and offices were also centralized spatially in order to promote cooperation and accessibility. Close cooperation with civil society actors is specific for the new structures in SmallNorthernCity (Head of Unit, Head of VolunteerSercive, SmallNorthernCity). In SmallNorthernCity like in NorthernCity, the new unit aims not only at dealing with the consequences of the situation of 2015/16, but more broadly with a diversifying society.

SmallNorthernCity's strategy of imitation and change went along, however, with a strategy of (limited) externalization. From spring 2017, the municipality obtained a break in the allocation of new asylum-seekers from first-reception centres; in addition, persons granted international protection elsewhere after November 2017 were banned from moving there (Zuzugsstopp) (Coordinator for Migration and Participation; Head of Department, SmallNorthernCity). Unlike SouthernCity, SmallNorthernCity did not refuse to accept asylumseekers during the height of the refugee immigration movement, but later requested the regional government's support. For SmallNorthernCity, these measures were part of an enduring quarrel with neighbouring municipalities and aimed at pushing those to greater efforts in social housing and social inclusion (Head of Department, Coordinator for Migration and Participation, SmallNorthernCity). Furthermore, the government of Lower Saxony had created incentives for municipalities to apply for a ban, as this was linked to financial support by the regional state: SmallNorthernCity received two million euros for 2017, and similar amounts for the following two years (Head of Department, Head of Unit, SmallNorthernCity) for integration measures.

\section{"... and then, the refugees ruined all our efforts": framing immigration and uncertainty reduction}

Nevertheless, in SmallNorthernCity like in NorthernCity, the framing of the situation and their capacities of dealing with it differed from those in SouthernCity. While the SmallNorthernCity administration in particular emphasized that the fundamental uncertainty experienced by municipalities was due to poor planning and organization and political mistakes at higher levels, they also stressed their experience in including new migrants in local society successfully. Decades ago, they had begun to adapt their local policies and structures - especially regarding housing, urban planning and social work - to a continuously diversifying local population. This goes along with pride in the achievements of the administration and civil society, in the existing structures 
as well as their adaptability. According to members of the administration, the population deals with new immigration "in a laid-back manner", SmallNorthernCity has "very good social work", sufficient social housing and a very good infrastructure (Coordinator for Migration and Participation, SmallNorthernCity). Furthermore, officials and bureaucrats in SmallNorthernCity stressed the importance of the municipality's working-class heritage and strong culture of social justice and welfare (Head of Office; Head of Unit, SmallNorthernCity). Accordingly, "super" was also the central attribute with which officials and bureaucrats in SmallNorthernCity characterized their handling of the situation in 2015-16 and their city, where "everyone would like to live" (Coordinator for Migration and Participation, SmallNorthernCity).

In NorthernCity - a city with fewer experiences in dealing with migrationrelated diversity - significantly, the head of the new Office for Immigration and Integration as well as the heads of its two units stressed the capacities and the potential of the new structures and the comparative advantage they had due to the restructuring. As described above, they, too, described the period of fundamental uncertainty in 2015 and 2016 as challenging, but put even more emphasis on the opportunities it had created (Head of Office, Heads of Unit, NorthernCity). They expressed pride in the instruments and measures the new office offered for better social and urban planning in the realm of refugee and migrant reception and participation - including improved and encompassing statistics and control, social work, training -, for improved cooperation within the administration, for a more sophisticated and inclusive concept of "integration" (Head of Office, Heads of Unit, NorthernCity) as well as in their adaptation to potential future developments: "NorthernCity will be prepared" (Head of Unit, NorthernCity). Furthermore, NorthernCity became part of the European network "Arrival Cities", founded in 2015 "against a backcloth [sic] of rising discrimination and prejudice against immigrants" and in order to bring together cities who "had to tackle the new and old challenges to ensure the migrants' integration" (ArrivalCities n.d.). In 2018, it became a member of the "Safe Harbour" movement of cities and towns willing to accept additional migrants rescued in the Mediterranean Sea (Seebrücke n.d.). The city thus positioned itself proactively as an actor in translocal networks demonstrating its - at least discursive ${ }^{12}$ openness.

In SouthernCity, a "Safe Harbour" city since 2019 (Seebrücke n.d.), in contrast, the framing is less clear-cut. SouthernCity, too, is described as an open city, characterized by its academic tradition and by its liberal stance on immigration and legal status - especially in comparison with neighbouring towns. Simultaneously, the same officials use racist stereotypes when referring to refugees and other migrants, while others highlighted the fact that residents in an upper-class / upper middle-class neighbourhood including the head of a university of applied sciences located there had argued most 
outspokenly, and in racist terms, against the opening of a new accommodation centre there (Head of Office; Head of Unit; Head of Department; SouthernCity).

Most significantly, the rapid immigration of refugees in 2015/16 was perceived as hampering urban development and progressive change. One head of department feared that the regional state might not cover the municipality's medium- and long-term expenditures for social benefits that were likely to arise from the reception of several hundred refugees (Head of Department, SouthernCity), while one head of office saw the potential reunion of refugees with their families as a major problem, because it would increase the number of newcomers by the factor of seven or eight (Head of Office, SouthernCity).

Although not all responsible officials saw the reception of the newcomers as a necessary, but inconvenient duty, the general framing of the situation was one of an immense challenge that had not opened up new opportunities. In a public event on the municipality's efforts in climate protection, a member of the unit responsible for the event went as far as to say in her opening presentation: "[...] und dann haben uns die Flüchtlinge alles kaputt gemacht" "and then, the refugees ruined all our efforts ${ }^{13 "}$. While this event took place in December 2019, thus after the height of the rapid refugee immigration, it reflects well a general perception of the situation in retrospect.

\section{Discussion and conclusion}

The period of rapid refugee immigration created a situation perceived as a challenge in all three municipalities. As has been shown, this time was characterized by a major lack of information regarding the likelihood of future events and the consequences of municipal actors' decisions. According to Apelt and Senge's (2015) typology, it was thus marked not only by incertitude, but also by fundamental uncertainty. The administration did not collapse, however, but proved capable of dealing with migration-related uncertainty.

In the short term, all three cities relied on "emergency" measures that allowed them to structure responsibilities and cooperation in a different way than usual. While SouthernCity soon after returned to the status quo ante, the other two cities opted for structural change, imitating pioneering municipalities that had already implemented similar transformations. In line with theories of the sociology of organizations, we thus observe two types of uncertainty reduction: externalization and organizational change through imitation.

SouthernCity opted for a strategy of externalization by delegating its responsibilities partly to third-party actors. It also chose to rely on others when it comes to preventing a recurrence of the situation. In contrast, SmallNorthernCity and NorthernCity did not - or to a limited degree - pass their 
responsibilities on to others. They both created new structures following the example of Freiburg and other municipalities and thus chose a strategy of organizational change.

While it is beyond the scope of this study to draw conclusions about causality in a strict sense, it is nevertheless possible to identify differences that played an important role for the variance observed. Significantly, officials and bureaucrats in SouthernCity focused on the challenging character of the period of fundamental uncertainty and stressed the limited capacities of the municipality. Their counterparts in SmallNorthernCity and NorthernCity could build on previous experiences, were better prepared and had already envisaged smaller changes. While they described the time as equally challenging, they also strongly underlined the capabilities of their administrations. The framing of the situation and of the municipalities' capabilities and capacities thus diverges most clearly, highlighting similarities between NorthernCity and SmallNorthernCity - which, in structural terms, are rather different.

Following Schammann et al. (forthcoming), these differences in the framing of the situation - as well as of migration, diversity and social policy more generally - can be considered relevant factors for shaping the way municipalities deal with migration and diversity. Officials in SmallNorthernCity and NorthernCity framed the situation as opening up new opportunities. They perceived their municipal structures as - more or less - a match to the situation and as adaptable enough for encompassing change. Unlike their SouthernCity counterparts, they did not emphasize the longer-term uncertainty the rapid immigration of refugees induced, but the strategies they favoured for reducing it. Especially officials in SmallNorthernCity also expressed their pride in the working-class and migration heritage of their city that made them adopt a "welfare" approach to immigration, including refugee reception.

Further qualitative studies within administrations will provide additional insights contributing to a specification of the role of framing in local refugee reception, migration policies and structural change.

\section{Notes}

1. The term "refugee" as it is used here includes asylum-seekers, recognized refugees, and other persons seeking international protection - with or without a specific legal status. It is thus not restricted to persons granted international protection in accordance with the Geneva Convention.

2. At the same time, this did not exclude important forms of exclusion experienced by asylum-seekers and refugees (cf. a special issue co-edited by the author as well as Schader forthcoming).

3. For a current state of the art, see also Schammann et al. forthcoming.

4. With almost eight million inhabitants, Lower Saxony is Germany's fourth largest state. 
5. SmallNorthernCity: seven of 44, NorthernCity: two of 50, SouthernCity: zero of 46.

6. NorthernCity and SmallNorthernCity are independent cities (kreisfreie Städte) and do not belong to a larger administrative district (Landkreis); SouthernCity is specific in that it belongs to a district (kreisangehörige Stadt), but in many aspects is independent of it and, importantly, does not depend on decisions made in or cooperation with the district.

7. According to the German Statistical Office, persons have a "migration background" if they or at least one parent were not born as German citizens (Statistisches Bundesamt 2013, 26).

8. The central topic of the interviews was the perception of the rapid asylumseeker immigration in 2015-16 and the consequences drawn locally in the years directly after the Chancellor's claim that Germany would manage the challenges. In the focussed cities, some fifteen interviews were conducted. For the period of 2016-17, additional data was collected in SouthernCity in a large pilot project coordinated by the author. This project's focus were asylumseeker reception and the needs and aspirations of asylum-seekers The data consists of interviews with officials, social workers and refugees, participant observation in shelters, focus group discussions with refugees and a large body of clippings from local two newspapers.

9. Launched in 2016 and funded by the federal government, the FIM programme aims at including asylum-seekers quickly into the labour market, while supporting their learning German. It allows state and welfare organizations and companies running shelters for asylum-seekers etc. to employ asylum-seekers for 80 cents / hour (https://www.bmas.de/DE/Themen/Arbeitsmarkt/Infos-fuerAsylsuchende/arbeitsmarktprogramm-fluechtlingsintegrationsmassnahmen. html).

10. Rohmann and Hruschka (forthcoming) identify over 30 changes in the respective legislation, partly contradictory, between 2015 and 2019.

11. Charged also with deportation, legal status etc.

12. At the time of writing, the Federal Ministry of the Interior was blocking the direct allocation of migrants to one of the "Safe Harbour" cities.

13. In reducing the emissions of municipality-owned buildings.

\section{Disclosure statement}

No potential conflict of interest was reported by the author(s).

\section{References}

Apelt, Maja, and Konstanze Senge. 2015. Organisation und Unsicherheit. Wiesbaden: Springer Fachmedien Wiesbaden.

ArrivalCities Network. n.d. https://urbact.eu/arrival-cities.

Baumgärtel, Moritz, and Barbara Oomen. 2019. "Pulling Human Rights Back in? Local Authorities, International Law and the Reception of Undocumented Migrants." The Journal of Legal Pluralism and Unofficial Law 51 (2): 172-191.

Bygnes, Susanne. 2019. "A Collective Sigh of Relief: Local Reactions to the Establishment of New Asylum Centers in Norway." Acta Sociologica. Advance online publication. 
Caponio, Tiziana, and Maren Borkert, eds. 2010. The Local Dimension of Migration Policymaking. Amsterdam: Amsterdam University Press.

Caponio, Tiziana, Peter Scholten, and Ricard Zapata-Barrero, eds. 2019. The Routledge Handbook of the Governance of Migration and Diversity in Cities. Abington: Routledge.

Dahlvik, Julia. 2017. "Asylum as Construction Work: Theorizing Administrative Practices." Migration Studies 5 (3): 369-388.

Dequech, David. 1999. "Expectations and Confidence Under Uncertainty." Journal of Post Keynesian Economics 21 (3): 415-430.

Dick, Eva, and Benjamin Schraven. 2017. "Urban Governance of Forced Displacement: Premises, Requirements and Challenges in the Light of New Humanitarian Trends." Raumplanung 193 (5): 23-29.

DiMaggio, Paul, and Walter W. Powell. 1983. "The Iron Cage Revisited: Institutional Isomorphism and Collective Rationality in Organizational Fields." American Sociological Review 48 (2): 147-160.

Doomernik, Jeroen, and Birgit Glorius. 2016. "Refugee Migration and Local Demarcations: New Insight into European Localities." Journal of Refugee Studies 29 (4): 429-439.

Ellermann, Antje. 2006. "Street-level Democracy: How Immigration Bureaucrats Manage Public Opposition." West European Politics 29 (2): 293-309.

Eule, Tobias. 2014. Inside Immigration Law: Migration Management and Policy Application in Germany. Research in Migration and Ethnic Relations Series. London: Routledge.

Filomeno, Felipe Amin. 2017. Theories of Local Immigration Policy. Cham: Springer International Publishing.

Glick Schiller, Nina, and Ayse Çaglar. 2010. Locating Migration: Rescaling Cities and Migrants. Ithaca: Cornell University Press.

Hahlen, Johann, and Hannes Kühn. 2016. "Die Flüchtlingskrise als Verwaltungskrise Beobachtungen zur Agilität des deutschen Verwaltungssystems." Verwaltung und Management 22 (3): 157-167.

Hesse, Joachim Jens. 2015. "Staatsversagen? Bankrotterklärung Europas? Anmerkungen zur Flüchtlingskrise." Zeitschrift für Staats- und Europawissenschaften 13 (3): 336-355.

Jacobs, Andreas, and Meike Bolz, n.d. "Verfügbares Einkommen der privaten Haushalte in Niedersachsen 2012." https://www.statistik.niedersachsen.de/download/95862.

Jørgensen, Martin Bak. 2012. "The Diverging Logics of Integration Policy Making at National and City Level." International Migration Review 46 (1): 244-278.

Kleist, J. Olaf. 2018. "Flucht- und Flüchtlingsforschung in Deutschland: Akteure, Themen und Strukturen, with a contribution of Lars Wirkus." Flucht: Forschung und Transfer. State-of-Research Papier 01. Osnabrück: (IMIS) / (BICC).

Kühn, Manfred, and Sybille Münch. 2019. "Zuwanderungspolitik - ein neues kommunales Aufgabenfeld?" disP - The Planning Review 55 (3): 22-30.

Martínez-Ariño, Julia, Michalis Moutselos, Karen Schönwälder, Christian Jacobs, Maria Schiller, and Alexandre Tandé. 2019. "Why Do Some Cities Adopt More Diversity Policies Than Others? A Study in France and Germany." Comparative European Politics 17 (5): 651-672.

Moutselos, Michalis, Christian Jacobs, Julia Martínez-Ariño, Maria Schiller, Karen Schönwälder, and Alexandre Tandé. 2020. "Economy or Justice? How Urban Actors Respond to Diversity." Urban Affairs Review 56 (1): 228-253.

Rohmann, Tim, and Constantin Hruschka. forthcoming. "Excluded by enhanced migration management?" 
Schader, Miriam. 2019. "Total spontan? 'Krisen' bearbeitung in der lokalen Aufnahme Geflüchteter." In Migration, Refugees and Asylum. Concepts, Actors, Practices Since the Second World War in Global Perspective, edited by Agnes von Bresselau, 381396. Göttingen: Vandenhoeck \& Ruprecht.

Schader, Miriam. forthcoming. "Refugees as "Disciplinary Individuals"? Exclusion and Inclusion in Local Asylum-seeker and Refugee Reception and the German Welfare System."

Schammann, Hannes. 2018. "Migrationspolitik." In Soziale Arbeit in der Migrationsgesellschaft: Grundlagen - Konzepte - Handlungsfelder, edited by Beate Blank, Süleyman Gögercin, Karin E. Sauer, and Barbara Schramkowski, 67-85. Wiesbaden: Springer Fachmedien Wiesbaden.

Schammann, Hannes, Danielle Gluns, Christiane Heimann, Sandra Müller, Tobias Wittchen, Christin Younso, and Franziska Ziegler. forthcoming. "Ambitious Activity above a Pattern of Passivity: Re-Dimensioning the 'Local Turn' in Migration PolicyMaking."

Schiller, Maria. 2019. "The Local Governance of Immigrant Integration in Europe: The State of the Art and a Conceptual Model for Future Research." In The Routledge Handbook to the Governance of Migration and Diversity in Cities, edited by Tiziana Caponio, Peter Scholten, and Ricard Zapata-Barrero, 204-215. Abingdon: Routledge. Scholten, Peter. 2019. "Two Worlds Apart? Multilevel Governance and the Gap between National and Local Integration Policies." In The Routledge Handbook to the Governance of Migration and Diversity in Cities, edited by Tiziana Caponio, Peter Scholten, and Ricard Zapata-Barrero, 157-167. Abingdon: Routledge.

Scholten, Peter, and Rinus Penninx. 2016. "The Multilevel Governance of Migration and Integration." In Integration Processes and Policies in Europe, IMISCOE Research Series, edited by Blanca Garcés-Mascareñas and Rinus Penninx, 91-108. Cham: Springer International Publishing.

Seebrücke. n.d. https://seebruecke.org/startseite/sichere-haefen-in-deutschland/.

Statistisches Bundesamt: Zensus 2011: Ausgewählte Ergebnisse, Wiesbaden. 2013. 